
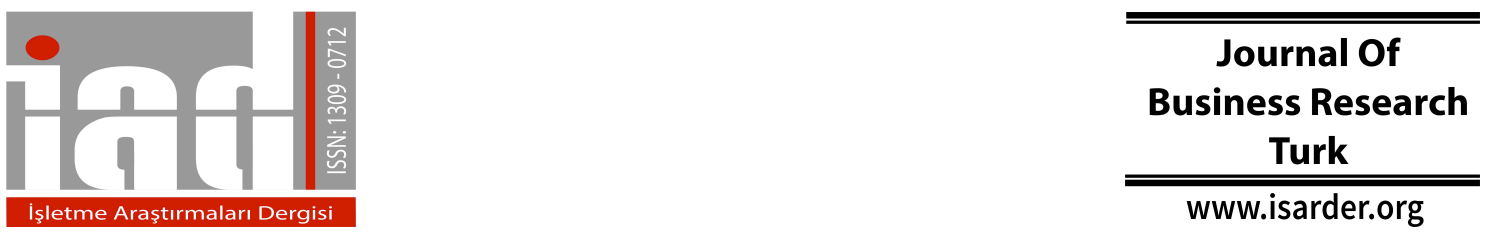

\title{
Corporate Social Responsibility In Turkey: An Analysis Through Web Sites
}

\author{
Burcu EKER AKGÖZ \\ Bahçeşehir University \\ Faculty of Communication \\ Department of Public Relations \\ İstanbul, Turkey \\ burcu.eker@comm.bahcesehir.edu.tr
}

\author{
Elif ENGIN \\ Bahçeşehir University \\ Faculty of Communication \\ Department of Public Relations \\ İstanbul, Turkey \\ elif.engin@,comm.bahcesehir.edu.tr
}

\begin{abstract}
In today's business environment, there is no chance for a corporation to be succeeded simply by doing profit oriented business. Corporations are the living entities along with their stakeholders therefore corporations are expected to be responsive on the cultural, environmental and economic issues of society. Socially responsible programs that corporations execute would contribute the corporate image and reputation. Furthermore, these programs benefit both corporations and society.

The aim of this study is to examine the presence and organization of information on corporate responsibility present on the corporate web sites of companies which are in the Capital top 500 list. We will choose the top 100 companies on the top 500 list. By using content analysis, identified corporate responsibility issues will be analyzed. In this study, the information given in the web sites of these top 100 companies will be analyzed. We will be examining how the information is organized, presented, and related to the corporate responsibilities.
\end{abstract}

Keywords: Public Relations, Corporate Social Responsibility, Web-Sites

\section{Introduction}

In the last few years, business life paid a great attention to corporate social responsibility (CSR) to face a score of challenges namely globalization, sustainable development, finance, governance, communications, ethics among others. In competitive business environments, economic and environmental rotation of the world, and more sensitive societies cause corporation's business philosophies to be altered. The companies comprehended that they must consider the cultural and social values of the environment and society they live in. Thus, by doing business with this sense of social responsibility these corporations arose. This circumstances the companies' responsibilities are not just limited to economic actions but evolve into legal, ethical, environmental and social actions. 
Nobel Prize winner economist Milton Friedman declared on a feature report that corporations exist to provide products and/or services that produce profits for their shareholders. He said that a corporation's purpose is to maximize returns to its shareholders, and that since (in their view), only people can have social responsibilities, corporations are only responsible to their shareholders and not to society as a whole. Although they accept that corporations should obey the laws of the countries within which they work, they assert that corporations have no other obligation to society. But in today's business world this statement becomes antiquated. According to Salim Kadıbeşegil(2008), during The Davos Economic Forum in 2002, the CEO's of the world's biggest companies appended their signature to a declaration which disposed of the argument of Friedman. The UN led and embraced this declaration. Thus, the UN declared that "This is the end of the time period in which doing business for just making a profit."

Philip Kotler lists practicing corporate social responsibility as one of 5 factors that help a brand become well respected globally. Others mentioned are having quality products \& services, good financial track record, good management or leaders and innovations. Kotler said that the global brands that are admired internationally have similar characteristics, such as considering the needs of all stakeholders and not just shareholders; executive salaries are relatively modest and they generally have an open door policy to reach top management. (http://www.csreurope.org/news.php?type=\& action $=$ show_news\&news_id=594)

Corporate social responsibility has a direct impact on corporate reputation, brand awareness and being a preferable corporate or brand. Corporate social responsibility is a concept beyond philanthropy.

A survey of Turkey's CSR Report that was carried out by United Nations (2008) emphasized that there is confusion in business environments about the description of CSR, this confusion then occurs in CSR practices. International companies which operate in Turkey affect CSR practices in a positive way. International companies have a positive influence on their local cooperators and suppliers. Thus, this influence becomes an impulsive force for Turkish companies. "The Principles of Corporate Government" announced by SPK (Capital Markets Board of Turkey) made an awareness and perception about CSR practices and reporting shareholder policies.

(http://www.unglobalcompact.org/docs/networks_around_world_doc/Network_material /CSR_Report_in_Turkish.pdf)

From this point of view this study's aim is to analyze how the companies present information about corporate responsibility on corporate web sites. The authors will come up with an answer to this question. What themes that are related to corporate responsibility are present on the corporate web sites?

\section{Literature Review}

Corporate Social Responsibility not only provides better competitive advantages for corporations in the international market, better labor standards and conditions for workers and employees in the business sector (if that's what you mean), environmental protection and more collaboration between civil society and private sector; also it is very signifi cant for the realization of sustainable development goals and for strengthening local communities and societies. In this regard every person and 
organization has a responsibility not only to themselves but to the stakeholders within society (http://kssd.org/wp-content/uploads/2013/06/csrbaselinereport.pdf).

There are several widely cited definitions of corporate social responsibility (CSR) in literature and there is no universally accepted definition of this concept. Because CSR takes part in community, business, ethics, marketing and public relations etc. For purposes of focused discussion and applications for best practices, the authors prefer the use of the term corporate social responsibility and offer the following definition: Corporate social responsibility is a commitment to improve community wellbeing through discretionary business practices and contributions of corporate resources (Kotler and Lee, 2005, p.2-3). A company's sense of responsibility towards the community and environment (both ecological and social) in which it operates. Companies express this citizenship (1) through their waste and pollution reduction processes, (2) by contributing educational and social programs, and (3) by earning adequate returns on the employed resources. (http://www.businessdictionary.com/ definition/corporate-social-responsibility.html). Corporations not only try to accomplish their business aims but also they are interested in to take part in socially responsible activities. Therefore, they try to satisfy the expectations of their publics.

Two perspectives can be offered to elaborate the meanings of CSR. From an outside-in perspective, a socially responsible corporation should "make a profit, obey the law, be ethical, and be a good corporate citizen" (Carroll, 1991, p.43); while in an inside-out angle, CSR spells out corporate commitments in contributing to employees and their families, local communities and the society (World Business Council for Sustainable Development, 2000). CSR can not be defined as planned activities for external environment of corporation also is set of activities for employees and their families (Jiang and Wong, 2016, p.852).

Corporate Social Responsibility as a concept was originally developed by author Howard Bowen in 1953 in his book Social Responsibilities of the Businessman (Bowen, 1953). Bowen offered one of the earliest definitions seeing CSR as the "obligations of businessmen to pursue those policies, to make those decisions, or to follow those lines of action which are desirable in terms of the objectives and values of our society" (1953, p.6). Since then, the field has evolved assuming different names such as corporate social responsiveness (in the 1970s) and corporate social performance (in the 1980s). This evolution also reflects an increase in awareness in important areas of action and performance that the early definitions had overlooked (Carroll, 1991). (Soh, Sriramesh, Ng and Luo,2006, p.2)

Looking through the concepts development, since Bowen, a broad range of possible definitions have been proposed, ranging from Milton Friedman's view that the only social responsibility of a company is, to use its resources and engage in activities designed to increase its profits so long as it stays within the rules of the game" (Friedman, 1962, p.133) to ideas that view a company's objective as becoming a Good Corporate Citizen (Waddock, 2002; 2004). The idea of Corporate Social Responsibility is closely related to the concept of sustainability. Sustainability usually implies the consideration of the so-called "triple bottom line" of economic, social, and environmental performance. More generally, within the overall objective of Corporate Social Responsibility, companies are expected to operate in a way that secures long- 
term economic performance while avoiding short-term actions that are socially detrimental or environmentally wasteful (Van Marrewijk, 2003).

In the 1980s, we witnessed fewer original definitions of CSR, more attempts to measure and conduct research on CSR, and alternative the-matic frameworks. In terms of definitional contributions, the contributions of Jones, Drucker, Wartick and Cochran, and Epstein stood out. Finally, in the 1990s, the CSR concept transitioned significantly to alternative themes such as stakeholder theory, business ethics theory, CSP, and corporate citizenship. During that period, it should be noted that writers did not reject the CSR concept, but there were no new definitions added to thebody of literature. Wood(1991)expanded and set forth a CSP model that captured CSR concerns. During that time, there was a con tinuationofatrend begun earlier to operationalize the CSR concept and to articulate other concepts that were consistent with CSR theory but thattook alternative emphases or themes as their centerpiece. In virtually allcases, these new directions and themes were consistent with and built onthe CSR definitions and constructs discussed in this article. Furthermore, the language of CSR remains in active use today (Carroll, 1999, p.291-292).

As mentioned before Kotler and Lee' definition (2005, p.3) the key element of corporate social responsibility is the word discretionary. We not refering here to business activities that are mandated by law or that are moral or ethical in nature and perhaps therefore expected. Rather, we are referring to a voluntary commitment a business makes in choosing and implementing these practices and making these contributions. The term community well-being in this definition includes human conditions as well as environmental issues. Business world realize the importance of being in social actions is not enough for their image. But these actions should be in different areas such as environmental and economic. In today's competitive business world having a good image and strong reputation can be obtained by doing sustainable social responsibility activities.

The fundamental definition of corporate social responsibility is defined in an article by Carroll (1979), as "The social responsibility of business encompasses the economic, legal, ethical, and discretionary expectations that society has of organizations at a given point in time" (p. 500). Carroll assert these responsibilities as a pyramid. The first step of this pyramid is economic responsibilities. He suggests that the first and foremost social responsibility of business is economic in nature. As such it has a responsibility to produce goods and services that society wants and to sell them at a profit. All other business roles are predicated on this fundamental assumption. After accomplishing economic responsibilities a corporation has legal responsibilities which requires laws and regulations. Society expects business to fulfill its economic mission within the framework of legal requirements. As a third step of the pyramid, Carroll advances the responsibility of a corporation to a higher level of ethics. Although the first two categories embody ethical norms, there are additional behaviors and activities that are not necessarily codified into law but nevertheless are expected of business by society's members. Suffice it to say that society has expectations of business over and above legal requirements. Carroll puts discretionary responsibilities at the top of the pyramid These responsibilities are those about which society has no clear-cut message for business- even less so than in the case of ethical responsibilities. They are left to individual judgment and choice. In this step the roles of corporations are purely voluntary and the decision to assume them is guided only by a business's desire to 
engage in social roles riot mandated, not required by law, and not even generally expected of businesses in an ethical sense. Examples of voluntary activities might be making philanthropic contributions, conducting in house programs for drug abusers, training the hardcore unemployed, or providing day-care centers for working mothers. (Carroll, 1979, p. 500).

In the year when this pyramid was formulated, the economic element was the basic item for business environments. Carroll had taken the attention from economy to law, corporate profile and ethics. These are all the criterias for CSR, and also the items for being a good citizen. The firms which take part in social responsibility actions, are more valuable for their publics. They also have a 'good image' which helps to improve the firms 'reputation'. Image can be both positive and negative, but when it comes to 'corporate reputation', the word includes positive meaning by the way the term reminds, so it doesn't include a negative meaning (Peltekoğlu, 2007, p.589). In order for companies to know the importance of corporate social responsibility they must understand their consumers and target audiences.

Since 1990s, PR producers have been sending noticeably more messages about the socially responsible intentions and behaviors of their organizations and groups towards their stakeholders. These socially responsible intentions and behaviors can also be called corporate ethics in action (Moloney, 2006, p.106).

The power of public opinion became part of strategy of large businesses with the rise of corporations during the twentieth century. At the beginning of the century, newspapers and magazines were the only mass media. Radio, Tv and film took on greater influence. Then Marshall McLuhan opened the eyes of the world to the power of communications media. Corporations have seized the opportunity to influence audiences internally and externally with technology and media ever since (Goodman, 1998, p.222).

Each day corporations, political groups, and non-profit organizations tap into an internet, and utilize the World Wide Web. Virtually every industry, product, activity, and public pursuit is referenced somewhere on the WWW. Public relations practitioners and scholars have expressed great interest in the Web. Organizational Web sites and homepages serve such public relations functions as outlets for news releases, opportunities for research of publics, and dissemination of organizational information. These Web sites also offer opportunities for immediate response to organizational problems and crises. But, for all of its public relations potential, the World Wide Web still remains underutilized by many organizations and underexamined by scholars as a tool for building organizational-public relationships (Kent and Taylor, 1998, p.321$322)$.

The internet has become, in a very short time, an indispensable communication tool for organizations. Stuart and Jones (2004, p.85) point out that the internet can fulfil a broad range of functions: '. . . a persuasive advertising medium, a means to educate or inform customers, a way to communicate and interact with buyers, a means of building and maintaining customer relationships, or simply a source of entertainment.' Sullivan (1999, p. 194) explains that corporate web sites act as "gatekeepers, uncertaintyreducing information sources, and image-creating tools". Similarly, Clark (2000) says that the internet allows for strategic communication with stakeholders, as it permits the activity of the audience and thus has great potential for active audiences to seek 
information on corporate responsibility. The internet gives many choices for customers and target audiences. Providing them with information about corporate profile, products, social, economic and environmental actions. These issues help them to decide 'which company is best for them?'

Web pages have several attractive features for corporations. They tend to serve more active, information-seeking audiences than the more passive publics who are reached via traditional mass media. Accordingly, an organization can assume that visitors to its Web site have some kind of active interest in the entity. Web pages can also employ interactive features to collect information, monitor public opinion on issues, and proactively engage citizens in direct dialogue about a variety of matters. The developing medium further allows an organization to speak to and serve a variety of different publics. While a traditional mass media vehicle may be aimed at a particular group, a single Web site may have a number of sections that target the unique wants atid needs of several audiences (Stuart \& Greg, 1999, p.456). As technology advances more and more people are using the internet and accessing company websites, this gives companies the opportunity to showcase themselves by providing more detailed information about their identity. Customers choose products not only out of necessity, but also for their desires. The best way to be successful and leave the competitors behind, is to take part in corporate social responsibility actions.

Badarocco (1998) suggested that the Web and Internet may stimulate corporate social responsibility practices since information about organizations is increasingly accessible and transparent. From this point, it is a beneficial opportunity for companies to build a relationship with the public. In a survey of Fortune 500 companies, they found that 90 percent had Web pages and that 82 percent of the sites addressed at least one corporate social responsibility issue (Gower\&Cho,2001, p.81). So the companies in today's global world know the importance of social actions and apply it to their activities in different areas.

The advanced technology give opportunity to users to become more participative on the internet. Not only social media but also interactive web sites obtain dialogical communication between corporations and their publics. Therefore, as an effective and reliable information source the web sites are the visible side of the corporations. Corporate web sites are the tool for disseminating information about corporations. In today's technological world corporations that don't have an active web sites are perceived dated and behind the times. Hence, major corporations have their own web sites and through their web sites they communicate their socially responsible activities.

\section{Methodology}

The aim of this study is to analyze the presence of information on corporate responsibility that is on the corporate web sites of companies which operates in Turkey.

The research objective has been defined using the following research question:

What themes that are related to corporate responsibility are present on the corporate web sites of companies?

\section{Sampling}

The sample that was selected for this study of the corporate web sites from the companies that were the top 100 of the list of the 500 most admired companies of the 
Capital in 2014 (Capital Dergi, Ağustos, 2015). How the information is presented in the web sites of these top 100 companies had been analyzed.

\section{Data Collection Procedure}

By using content analysis, identified corporate responsibility issues had been analyzed. In this study the methodology used by P. Capriotti and A. Moreno (2007) had been applied. Capriotti and Moreno had determined ten issues that correspond to corporate responsibility themes. And these are: corporate profile, product and services, employment and human resources, economic action, social action, environmental action, corporate governance, corporate ethics, relationship with publics and external criteria. (Table 1).

Table 1. Issues of Corporate Responsibility

\begin{tabular}{ll}
\hline \multicolumn{1}{c}{ Issue } & \multicolumn{1}{c}{ Definition } \\
\hline Corporate profile & $\begin{array}{l}\text { Explanation of its view, values and corporate strategy. Presentation } \\
\text { of the company's property, structure and legal form; divisions, } \\
\text { subsidiaries and countries with which it operates. Explanation of } \\
\text { results. }\end{array}$ \\
\hline Products and services & $\begin{array}{l}\text { Explanation of its products, and brands from a corporate perspective } \\
\text { and not from a commercial one (type of products, raw materials, } \\
\text { manufacture systems, etc.) }\end{array}$ \\
\hline $\begin{array}{l}\text { Employment and } \\
\text { human resources }\end{array}$ & $\begin{array}{l}\text { Declarations and explanations of its systems of contract, promotion, } \\
\text { evaluation and dismissal. Declarations and explanations about } \\
\text { human rights in the company (children labor, discrimination. ..) }\end{array}$ \\
\hline Economic action & $\begin{array}{l}\text { Declarations and actions related to the economic impact of the } \\
\text { company in its local, regional, national and supranational } \\
\text { environment }\end{array}$ \\
\hline Social action & $\begin{array}{l}\text { Declarations and actions related to the company involvement in } \\
\text { social issues. }\end{array}$ \\
\hline Environmental & $\begin{array}{l}\text { Declarations and actions related to the company involvement in } \\
\text { environmental issues. }\end{array}$ \\
\hline $\begin{array}{l}\text { Corporate } \\
\text { governance }\end{array}$ & $\begin{array}{l}\text { Declarations and explanations of its transparency compromises in } \\
\text { the governance of the company. } \\
\text { Explanation of the structure of power, remunerations, } \\
\text { responsibilities, government departments, etc. }\end{array}$ \\
\hline Corporate ethics & $\begin{array}{l}\text { Declarations and explanations about its ethical compromises in } \\
\text { relation with the business and its groups of public. }\end{array}$ \\
\hline $\begin{array}{l}\text { Relationship with } \\
\text { publics }\end{array}$ & $\begin{array}{l}\text { Declarations and explanations about the interests, importance and } \\
\text { linking of the stakeholders with the company }\end{array}$ \\
\hline External criteria & $\begin{array}{l}\text { Declarations, explanations and linking with the national and } \\
\text { international criteria on aspects of the CSR/CC/SD }\end{array}$ \\
\hline Source: Caprioti and &
\end{tabular}

Source: Capriotti and Moreno, 2007, p.227

In order to attribute the web sites of these companies to the defined categories two coders were used in analyzing the web sites. To increase intercoder objectivity, the coders were briefed by explaining to them the nature and the meaning of the corporate responsibility issues and the definitions of each issue. Coding form was pre-tested after the training of the coders. The necessary refinements were made according to the results 
of pilot study. After that, the coders received coding sheets for each issue in the sample and each coder had attributed each web site to the defined categories.

Intercoder reliability level has been evaluated with Krippendorfs Alpha value that has been utilized in the testing of 15 nominal data, for 2 and more coders. Krippendorff (2013) determines a good KALPHA value as $\alpha \geq .800$, the value between $0.800>\alpha \geq 0.667$ is acceptable and the value $\alpha<0.667$ is not acceptable. This study's reliability level is $(\alpha=0,878)$ so it is an acceptable value for KALPHA (Krippendorff, 2013).

\section{Findings}

When the issues of corporate responsibility were analyzed, in general, the issues such as corporate profile, products and services and relationships with publics were taken place on corporate web sites at most. Corporate profile $(99 \%)$, products and services $(99 \%)$ and relationships with publics $(100 \%)$. The issues such as corporate ethics and external criteria were the least taken place on the corporate web sites. Corporate ethics $(71,7 \%)$ and external criteria $(89,9 \%)$. All the companies have web sites but $65^{\text {th }}$ firm was not disclosed in the list.

Table 2. Corporate Profile

\begin{tabular}{lcc}
\hline & Frequency & Percent \\
\hline Not present & 1 & 1,0 \\
\hline Present & 98 & 99,0 \\
\hline Total & 99 & 100,0 \\
\hline
\end{tabular}

The information about corporate profile is mainly divided in these groups; "about us", "corporate history" and "corporate management". In the "about us" section there is information about company's values, vision, mission and top manager's message. In the "corporate history" section there is information such as when the company was established, where the company is located and in which sector it is operated. In the "corporate management" section, they give information about the organizational structure and the name and resumes of the managers.

Table 3. Products and Services

\begin{tabular}{lcc}
\hline & Frequency & Percent \\
\hline Not present & 1 & 1,0 \\
\hline Present & 98 & 99,0 \\
\hline Total & 99 & 100,0 \\
\hline
\end{tabular}

The information about this issue is focused on products, services and activities, rather than explaining how the companies produce and sell their products. The information is mainly given about the product's price, photos and links.

Table 4. Employment and Human Resources

\begin{tabular}{lcc} 
& Frequency & Percent \\
\hline Not present & 11 & 11,1 \\
\hline Present & 88 & 88,9 \\
\hline Total & 99 & 100,0 \\
\hline
\end{tabular}


All of the companies have a section name called "Human resources" on their web sites. But in this section there is not so much information about labor rights and occupational safety. There is information about career development, promotion and acceptance criteria for the job. Most of the companies have a link for sending a CV.

\section{Table 5. Economic Action}

\begin{tabular}{lcc}
\hline & Frequency & Percent \\
\hline Not present & 19 & 19,2 \\
\hline Present & 80 & 80,8 \\
\hline Total & 99 & 100,0 \\
\hline
\end{tabular}

This issue was divided in two sections; "about us" and "relationship with shareholders". Included in the "relationship with shareholders" section is annual financial reports, financial meeting notes and the position in the stock market. These reports and information can be easily downloaded from the web site. In the "about us" section there was information about the companies financial situation and the capacity, and the location of the companies assets.

Table 6. Social Action

\begin{tabular}{lcc} 
& Frequency & Percent \\
\hline Not present & 26 & 26,3 \\
\hline Present & 73 & 73,7 \\
\hline Total & 99 & 100,0 \\
\hline
\end{tabular}

The majority of the companies inform about their vision for social responsibilities. The companies are aware of the importance of this issue and have a section on their web site devoted to this. When it comes to action, most of the 99 companies are involved in social actions. These actions include cultural and social issues, sponsorship and corporate philanthropy. A few companies have a special CSR Report.

Table 7. Environmental Action

\begin{tabular}{lcc}
\hline & Frequency & Percent \\
\hline Not present & 8 & 8,1 \\
\hline Present & 91 & 91,9 \\
\hline Total & 99 & 100,0 \\
\hline
\end{tabular}

91 companies out of 99 have a section about environment. In this section they inform the consumer about their environmental principles and values, the ISO 14000 certificate and green products. This issue is mostly placed under the section of social responsibility on the web sites. The companies are aware of the importance of "environmental action" but most of them do not have an environmental report. 
Table 8. Corporate Governance

\begin{tabular}{lcc}
\hline & Frequency & Percent \\
\hline Not present & 19 & 19,2 \\
\hline Present & 80 & 80,8 \\
\hline Total & 99 & 100,0 \\
\hline
\end{tabular}

80,8 percent of the companies have corporate governance reports. These reports can be found under the "relationship with shareholders" section and are available for download. Very few companies include declarations and explanations of its transparency compromises in the governance of the company.

Table 9. Corporate Ethics

\begin{tabular}{lcc}
\hline & Frequency & Percent \\
\hline Not present & 71 & 71,7 \\
\hline Present & 28 & 28,3 \\
\hline Total & 99 & 100,0 \\
\hline
\end{tabular}

The majority of the companies have general information about "corporate principles". But these principles do not include issues about ethics rules of the companies. Only 28,3 percent of the companies have a title called "ethics principles" under the relationship with shareholders section.

Table 10. Relationship with Publics

\begin{tabular}{ccc}
\hline & & \\
& Frequency & Percent \\
\hline Present & 99 & 100,0 \\
\hline
\end{tabular}

There is a lot of information for employees, consumers, media and shareholders on the web sites. There are archives of media news, downloadable press releases and articles about the companies. Most of the companies have a link named "contact us" which gives information about contacting the company such as an email or physical mailing address.

Table 11. External Criteria

\begin{tabular}{lcc} 
& Frequency & Percent \\
\hline Not present & 89 & 89,9 \\
\hline Present & 10 & 10,1 \\
\hline Total & 99 & 100,0 \\
\hline
\end{tabular}

Only 10 companies out of 99 have external criteria such as GRI-Global Reporting Initiative, UN Global Impact, some stock exchange index (FTSE 4 Good, Down Jones Sustainability Index). The majority of the national companies do not give information about the corporation's participation in external criteria. Some of the international companies which have the external criteria do not have a section in their Turkish web sites, they redirect to their international web sites. 


\section{Conclusion}

As an important component of corporate reputation, social responsibility activities are important public relations strategy for satisfying the needs of society. Therefore, corporations create symmetrical and informational communication with publics. Advanced technology give the opportunity to corporations to execute symmetrical and informational communication. Notedly, web pages as a visible tool for corporations on the internet obtain corporations to express themselves their stakeholders.

Hence, this study attempt to reveal that most admired companies both national and international level operate in Turkey consider using web sites as an effective communication tool for social responsibility activities. By using content analysis the issues of social responsibility set by Capriotti and Moreno were analyzed. The findings of this study indicates that Capital 100 the most admired companies give importance to the communication of their responsible behavior through their web sites. These responsible behaviors of these companies accure in these issues: economic, social, environmental, corporate profile and products and services. Our research's findings express that companies are wide aware of the importance of corporate responsibility of the communication by placing corporate responsibility information in a prominent section of the web site. It is explicit that the most admired companies utilize the new technology to disseminate information and tell their stories to their stakeholders.

The issues such as corporate profile, products and services and relationship with publics have the highest percentage out of these corporate responsibility issues. On the other hand corporate ethics and external criteria have the lowest percentage out of these issues. It is seen that the social responsibility indexes (FTSE 4 Good, Down Jones Sustainability Index, GRI, UN Global Impact) are not the important issues for companies at the international level. The companies which have a high level of external criteria are the international companies.

As a result, this study reveal that the companies have a significant level of consciousness of the importance of corporate responsibility and the given information through corporate responsibility on the web sites in general.

\section{References}

Badarocco, C. H. (1998). The Transparent Corporation and Organized Community. Public Relations Review, 24(3), p. 265-272.

Bowen, H. R. (1953). Social Responsibilities of the Businessman. New York: Harper \& Row.

Business Dictionary, (http://www.businessdictionary.com/definition/corporate-social responsibility.html\#ixzz40jV8plSR) (06.01.2016)

Capital Dergisi, Ağustos 2015, Sayı:2015/8

Capriotti P. \& Moreno A. (2007) Communicating Corporate Responsibility Through Corporate Web Sites in Spain. Corporate Communications: An International Journal Vol. 12 No. 3, p.221-237. 
Carroll, A. (1979). A Three-Dimensional Conceptual Model of Corporate Social Performance", Academy of Management Review, Vol. 4 No. 4, p.497-505.

Carroll, A. B. (1991). The Pyramid of Corporate Social Responsibility: Toward the Moral Management of Organizational Stakeholders. Business Horizons, 34 (4), p.39-48.

Carroll, Archie B. (1999). Corporate Social Responsibility: Evolution of a Definitional Construct Business \& Society, Vol. 38 No. 3, September, p.268-295.

Clark, A. (2000). "They're Talking About You: Some Thoughts About Managing Online Commentary Affecting Corporate Reputation", Journal of Communication Management, Vol. 5 No. 3, p.262-276.

Csr Europe, http://www.csreurope.org/news.php?type=\&action=show_news\&news_id= 594 (05.01.2016).

Friedman, M. (1962). Capitalism and Freedom. Chicago: University of Chicago Press.

Goodman, Michael B.,(1998). Corporate Communications For Executives, State University of New York.

Gower, Karla K.; Jung-Yul Cho. (2001). Use Of The Internet Curcillum in The Public Relations Curriculum Journalism \& Mass Communication Educator, Summer, Vol. 56 Issue 2, p.81-92.

Jiang Weiyan, Johnny K.W. Wong (2016). Key Activity Areas of Corporate Social Responsibility (CSR) in the Construction Industry: A Study of China, Journal of Cleaner Production, 113, p.850-860.

Kadıbeşegil, S. (2008). Şimdi Stratejik İletişim Zamanı. 1. Basım. İstanbul: Mediacat Kitaplar1

Kent, Michael L., Maureen Taylor (1998). Building Dialogic Relationships Through the World Wide Web Public Relations Review, 24(3), p.321-334.

Kotler P. \& Lee Nancy (2005). Corporate Social Responsibility: Doing The Most Good For Your Company And Your Cause. Unite States of America: John Wiley\&Sons, Inc. Hoboken, New Jersey.

Krippendorff, K. H. (2013). Content analysis: An Introduction To Its Methodology. Los Angeles, London: Sage Publications.

Kurumsal Sosyal Sorumluluk Derneği,http://kssd.org/wp-content/uploads/2013/06/ csrbaselinereport.pdf (12.12.2015).

Moloney Kevin, Rethinking Public Relations PR Propaganda and Democracy, (2006). Second Edition, Taylor\&Francis Books, Routledge, USA and Canada.

Peltekoğlu, B.F. (2007). Halkla İlişkiler Nedir?. 5. Basım. İstanbul: Beta Basım Yayım Dağıtım A.Ş.

Soh, Ting Ting; Sriramesh, K.; Ng, Chew Wee; Luo, Wanyin.(2006) Conference Papers -- International Communication Association, 2006-Annual Meeting, p.142. 
Stuart L. E., \& Greg B. L. (1999). Corporate World Wide Wibe Pages: Serving The News Media and Other Publics. Journalism \&Mass Communication Quarterly, Vol.7b.No.3, Autumn, p.456-467.

Stuart, H. and Jones, C. (2004), "Corporate Branding in Marketspace", Corporate Reputation Review, Vol. 7 No. 1, p.84-98.

Sullivan, J. (1999), "What are the functions of corporate home pages?", Journal of World Business, Vol. 34 No. 2, p.193-210.

Unglobal Compact http://www.unglobalcompact.org/docs/networks_around_world doc/Network_material/CSR_Report_in_Turkish.pdf (06.01.2016).

Van Marrewijk, M. (2003). Concepts and Definitions of CSR and Corporate Sustainability: Between Agency and Communion. Journal of Business Ethics, 44 (1), p.95-105.

Waddock, S. (2002). Leading Corporate Citizens: Vision, Values, Value Added. New York: McGraw-Hill.

Waddock, S. (2004). Parallel Universes: Companies, Academics, and the Progress of Corporate Citizenship.Business and Society Review, 109 (1), p.5-42.

World Business Council for Sustainable Development (Ed.), 2000. Corporate Social Responsibility: Making Good Business Sense. WBCSD, Geneva. (05.11.2015).

(CSR). http://www.wbcsd.org/work-program/business-role/previous-work/corporatesocial-responsibility.aspx (05.11.2015).

Wood, D. J. (1991). Corporate Social Performance Revisited. Academy of Management Review, 16, p.691-718. 